afforded enough protection for the DNA, but left scope for the necessary production of vitamin $\mathrm{D}$. When our dark-skinned ancestors started to migrate to the rest of the world, they first colonized regions that also had the strong sunlight to which their skin was already well adapted.

But dark skin was not adapted to the lower intensity of sunlight in northern Europe. It was simply over-protected, leading to problems producing vitamin $\mathrm{D}$. Jablonski argues that Europe could only have been colonized in the wake of a genetic mutation that altered both the nature and the distribution of melanins in skin, producing fair skin with a tendency for freckles. The European climate selected for a gene that might well have been lethal back in equatorial Africa. Evolutionary negotiation achieved a new compromise.

These historical events have reverberated down the years, from biological prehistory into human documented history. On the one hand there have been rocketing frequencies of skin cancers in fair-skinned people exposed to too much sun; on the other, rickets became a problem in both the white-skinned populations of sun-deprived, smoke-polluted industrial Britain, and the later, darker-skinned immigrants to a postindustrial but still relatively unsunny northern Europe. These issues hint at the medical truth that any deep understanding of our ideas of 'wellness' and 'illness' is only likely to come from the central concepts of evolutionary theory: reproductive fitness and adaptation. It is amazing that medicine does not make much more use of evolutionary ideas. It is surely a sea change that is long overdue.

John Galloway is at the Eastman Dental Hospital, 256 Gray's Inn Road, London WC1X 8LD, UK.

\title{
Chart toppers
}

\section{An exhibition explores the diverse ways of putting data on the map.}

\begin{abstract}
Martin Kemp
It was often said that geography was about maps, and history about chaps. But there are virtually no sets of data - about chaps or anything else - that cannot be mapped, although sometimes a visually appealing map can hide as much as it reveals. This is the message of the exhibition 'Places and Spaces: Mapping Science' (http://scimaps. org/exhibit/nyscience/), which can be seen at the New York Hall of Science until 25 February, after which it will tour the United States, Japan and Europe.

Curated by Katy Börner and Julie Smith of Indiana University, the exhibition contains a judicious selection of early and modern maps that lay out in various ways how historic cultures have charted the configuration of the Earth and the heavens. There are also specialist maps showing, for example, the distribution of telegraphic linkages, exports and poverty. The charts of scientific papers and patents by region are especially revealing, the latter showing the globe grotesquely morphed by 'fat' zones of high innovative activity.

Relationships between 'chaps' are also mapped, with networks of scientists and citations to the fore. Scientific disciplines are laid out according to their apparent relationships, and historical episodes are charted over time and space, most notably the discovery of DNA. Internet activity is plotted both architecturally and dynamically.

As the entities in the charts become more conceptual, the challenges become more complex and ultimately intractable. One set of juxtapositions in two dimensions necessarily precludes others that may be equally valid. An attempt to devise a twodimensional distribution of geographical terms ends up by separating space in its political dimension from urban planning, which cannot be right.
\end{abstract}

The non-topographical mapping seems

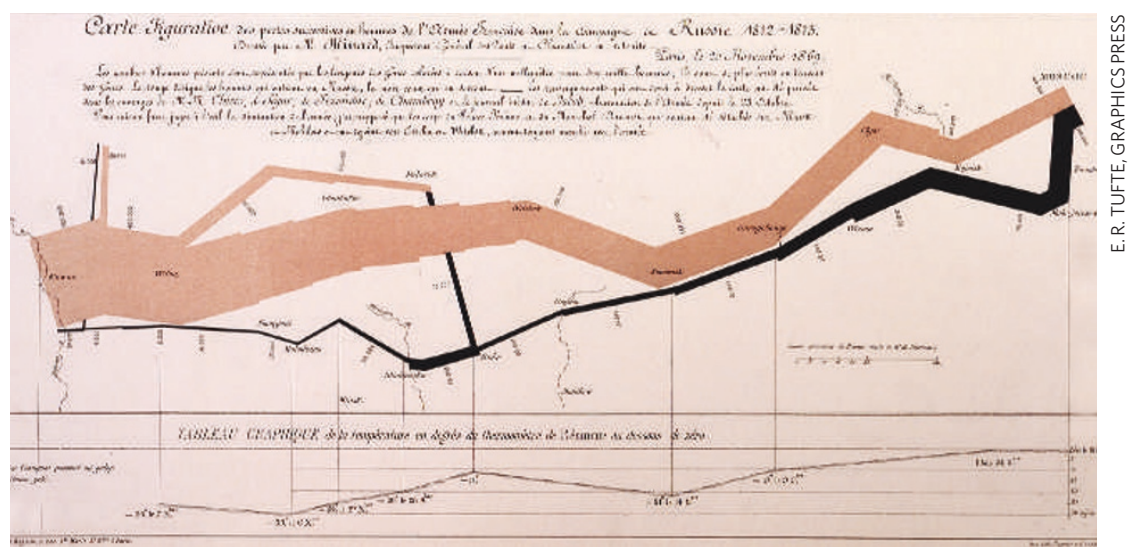

Decline and fall: Charles Joseph Minard mapped French losses in Napoleon's invasion of Russia.

distinctively modern. But one of the most effective statistical maps is also the earliest in the exhibition. In 1869, the retired French engineer Charles Joseph Minard produced a remarkable map of Napoleon's catastrophic invasion of Russia. It has hardly been surpassed for visual efficacy, and was acclaimed by the pioneer of 'cinematographic' photography, EtienneJules Marey, for its "brutal eloquence".

The basis of Minard's map (shown here) is a straightforward chart of the territory traversed by the French army in the winter of 1812-13, from Kowno (Kaunas) on the left to Moscow on the right. The width of the tinted strip represents the number of soldiers in the French army as it progresses eastwards. The plot doesn't thicken - quite the reverse in fact, beginning with a rearguard of 33,000 men branching off to remain at Polotsk. A series of abrupt falls then brings the company of 422,000 down to 100,000 by the time they reach Moscow.

The black line represents the retreating body of soldiers after they had sacked the Russian capital. The diminishing band is temporarily boosted from 20,000 to 50,000 as the rearguard rejoins, but at the River Berezina a Russian attack triggers a shambles. A stark black step graphically records the extent of the disaster.

Even more remarkably, Minard also charts one of the causal factors, the severe drop of temperature, on the army's return march during November and early December. By 6 December it had reached $-30^{\circ} \mathrm{C}$ and the army had been scythed down to a tiny rump of just 12,000 men.

Minard's map is both a vivid graphic and a tool for analysis, and forms the basis for further questions, such as the onset of infections, food deprivation, failure of equipment, and shortage of ammunition. Minard's map lays down a series of challenges in lucidity, functionality and potentiality that few since have fully met.

All this was accomplished by Minard after the age of 70. His last act was to publish the Napoleonic map in juxtaposition to one showing the Roman emperor Hadrian's disastrous losses on his return trip across the Alps from his northern expedition. It was designed to demonstrate the enduring human cost of war.

Martin Kemp is professor of the history of art at the University of Oxford, Oxford OX1 1PT, UK. His new book, Seen | Unseen, is published by Oxford University Press. 